\title{
The Shift in Money Demand: What Really Happened?
}

\author{
R. W. HAFER AND SCOTT E. HEIN
}

躍 ship in conventional macroeconomic models. When it appeared that during the mid-1970s the conventional specification had undergone an unforeseen shift, analysts devoted considerable ingenuity and research effort to testing altemative explanatory variables that wonld account for the change. ${ }^{1}$ Some specifications have produced marginally superior forecasting results. None, however, has been successful in explaining the post-1974 behavior of money demand.

Discussions of the temporal stability of parameters in econometic models generally differentiate between two distinct types of shift. One type of shift is an intercept, or level, shift, in which the estimated relationship simply undergoes at parallel change that leaves all marginal (slope) coeffictents anaffected. The other type of shift occurs when at least

\footnotetext{
"See, for example, Nichtel 1. Hamburger, "Behavor of the Money Stock: Is There a Puzzle?" Jom of Moretaty Ecomomics (nly 1977), pp. 265-88, Gillan Garcia and Simon Pak, "Some Clues in the Catse of the Missing Money, "Americtu Eeonamic Retiew (May 1979), pp. 330-34, and "The Ratio of Currency to Demand Deposits in the Unuted States, Joumal of Finatice (June 1979), ap. 703-15; Richatrd D. Poter, Themas D. Simpson and Eileen Marakopl, "Financial Innovation and the Monetary Aggregates," Brookings Paners on Economic Articity 1:1979), pp. 213-29:4. Robert Heller and Mohsin S. Khan, "The" Demand for Money and the Tem Semcture of Interest Pates," Journal of Political Economy (February 1979), op. 109-29; David 1. Bemett, Flint Braton, Eileen Mauskopt, Edward K. Oftenbacher and Richard D. Porter, "Fconometric Properties of the Redefined Monetary Aggregates," Board of Govenors of the Federal Resere System, Division of Reseath and Statisties February 1980), processed; G.S. Latumas and David E. Spencer, "The Stability of the Denand for Money: Evidence from the Post-1973 Period," Rectew of Economics and Statistics (Angust 1980, pp. 455-59; and Thomas D. Simpson and Pichard D. Porter, "Some Issues Involving the Definition and Interpretation of the Monetay Aggregates," in Controlling the Monetary Agrrexates Ill, Conference Series No. 23, (Federal Reserve Bank of Boston, 1980), pp. 161-234.
}

one of the relative slope coefficients changes. Surprisingly, previous examinations of the money demand puzzle have not explicitly investigated this basic distinction. The approach used in most previous work has been to presume that the change was not necessarily parametric, but due to the exchsion of an important variable. Hence, most studies focused on searching for the "correct" scale or opportunity cost measures to be used in the relar tionship..$^{2}$

Given the unsuccessful nature of this approach, we consider a different tack. The purpose of this article is to study explicitly the nature of the shilt in money demand. The evidence suggests that the conventional money demand specification was subject to a once-and-for-all level shift during the mid-1970s. Our result further suggest that the economic relationship underlying the estimated slope coefficients of the conventional equation remained remarkably stable thonghout the turbulent $1960-79$ period. This result conticts directly with much previous research.

The format of the paper is as follows: First, the apparent deterioration in the standard specification for $\mathrm{MI}$ during the $\mathrm{I} / 1960-\mathrm{IV} / 1979$ period is documented. ${ }^{3}$ Then, a procedure to determine likely point(s) of intercept change(s) in the money demand function is suggested and implemented. Finally, the implications of our findings are presented.

\footnotetext{
${ }^{2}$ For a critical analysis of attempts to repar the conventional specification, see R.W. Hafer and Seott E. Hein, "Evidence on the Tempond Stablity of the Demind for Money Retationship in the United States, "this Retion (December 1979), pp. 3-14.

the 1960-79 period is used to focus attention explicitly on the problems associated with money demand estimations through the mid-1970s. Estimation of the function throuth $1980 \mathrm{md} 1981$ would necessitate allowances for the possible effects of the credit control program and the change in Federil Reserve operating procedures. Such analysis would divent attention from the previously anresolved issue.
} 
Table 1

Regression Results for Equation 1

\begin{tabular}{|c|c|c|c|c|c|c|c|c|c|}
\hline \multirow[b]{2}{*}{ Perlod } & \multicolumn{2}{|c|}{ प8 } & \multicolumn{3}{|c|}{ Coefilicient ${ }^{\prime}}$, & \multicolumn{4}{|c|}{ Summary statsstos } \\
\hline & Constant & y. & $\mathrm{BCP}$ & $\mathrm{nCB}$ & $(\mathrm{MP})$ & $\bar{n}^{2}$ & $S E(x, 03)$ & n. & 10 \\
\hline $1 / 1960 / v / 1973$ & $\begin{array}{l}0.610 \\
(282)\end{array}$ & $\begin{array}{l}0125 \\
(269)\end{array}$ & $\begin{array}{l}0.016 \\
(3.02)\end{array}$ & $\begin{array}{r}0,032 \\
(208)\end{array}$ & $\begin{array}{l}0778 \\
(602)\end{array}$ & 0967 & 396 & 178 & 031 \\
\hline $1 / 960$ W/1979 & $\begin{array}{c}0.275 \\
(2,35)\end{array}$ & $\begin{array}{l}0.057 \\
2.51\end{array}$ & $\begin{array}{r}0.019 \\
(3.45)\end{array}$ & $\begin{array}{r}0.039 \\
(179)\end{array}$ & $\begin{array}{r}0962 \\
(13.55)\end{array}$ & 0.874 & 527 & -0.87 & 0,55 \\
\hline
\end{tabular}

Ail varkables enter logarthmicaly The log level equation is estimated using Hatanaka s procedure. The humbers in parentheses are absolute values of tstatistics

ZM 2 s the coefficient of determination corrected for degrees of heedon, SE is the standard erro of the estimated equation, his the Durbuh h statistic and tho is the latanaka estmate of the autocorrelation coefficient:

\section{THE SUIPT IN THE MONE DEMAND WUNCTON: ARENWWOK

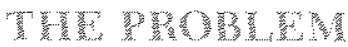

The conventional money demand specification is

(1) $\ln (M / P)_{t}=x_{0}+\beta_{1} \ln y_{t}+\beta_{2} \ln \operatorname{RCP} P_{t}$

$$
+\beta_{3} \ln \mathrm{RCB}_{t}+\beta_{t} \ln (\mathrm{M} / \mathrm{P})_{\mathrm{n}-1}+\epsilon_{\mathrm{t}}
$$

where $M$ represents the narrow definition of money (new M 1), ${ }^{4} \mathrm{P}$ is the implicit GNP deflator $(1972=100$ ), $y$ is real GNP (1972 dollars), RCP is the commercial paper rate and RCB is a weighted average of the commercial bank passbook rate. While many different money demand equations have been estimated, equation $l$ is generally the standard used for comparison.

Initial estimates of equation 1 revealed a significant degree of firstorder serial correlation in the error process. Previous estimates of equation 1 gen-

\footnotetext{
${ }^{4}$ In response to a changing funcial emvironment, the monetary aggregates were redefned. Thus, chedable deposits can now take the form of negotiable orders of withdrawal (NOW), atutomatic transer system (ATS) and credit mion share draft accounts. The old MI measure has been angmented by the introduction of these deposits. To the extent that this empirical redefinition of the "transactions" measure of money is induced by the advent of mear money substitutes, the ase of old M1 may reveal unstable relationships. Whether other financial innovations, such as money market mutual funds, repurchase agreements, ovemignt Eurodolars and the like, impinge upon the estimation of equation 1 is an empirical matter to be addressed below. Indeed, this line of reasoning hats been used to explain the poor post-1973 performance of equation 1. See Garcian and Pak, "Some Clues in the Catse of the Missing Money" and "The Ratio of Cumrency to Demand Deposits," and Porter, Simpson and Manskopf, "Financial Innovation," for examples of sach arguments.
}

erally have corrected this problem through the use of the Cochrme-Orcutt iterative procedure. This approach, however, yields inefficient coefficient estimates in the presence of a lagged dependent variable. ${ }^{5}$ Therefore, to obtain estimates that are (asymptotically) elficient and consistent, Hattinaka's residual adjusted Aitken estimation procedure is used in this study. ${ }^{6}$

Table 1 presents estimates of equation 1 for the I/1960-IV/1973 and I/1960-IV/1979 sample periods. The estimates for the ealier sample period are quite similar to those of other studies. These estimates suggest that real money balances adjust toward their equilibrium levels at the rate of about 22 percent per quarter, ceteris paribus. The esti-

${ }^{5}$ Roger Betancourt and Hary Kelefian, "Lagged Fndogenous Variables and the Cochrane-Oreut Pocedure," Econometrica (faly 1981), pp. 1073-78; and Micho Katanaka, "An Elficient Two-Step Estimator for the Dynamic Adjustment Model with Atatoregressive Errors," Joumal of Econometrics (September 1974), Dp. 199-220. It has been shown atso that the CochraneOrcut procedure may not iterate to a global mininmm of the regression standard error. See R. W. Hafer and Seott $\mathbf{E}$. Hein, "The Dynamics and Fstimation of Short-Run Money Denand," this Revietc (March 1980), pp. 26-35.

Eprevious money demand studies using the Hatanaka procedure inchude Chales Liebeman, "The Long-Run and Short-Run Demand for Money, Revisited,"Joumal of Monen, Credit and Banking (Febmary 1980), pp. 43-57; Laumas and Spencer, "Stability of the Demand for Money;" and Stutrt D. Mlen and A. W. Hafer, "Money Denand and the Term Structure of Interest Rates: Some Consistent Estimates," Joumal of Monetary Economics (forthcoming).

For an examination of the Hatanaka procedtre vis-a-vis Cochrame-Orcutt, Hildreth-Iu and maximum-likelihood estimiztion techiques, see Edward K. Offembacher, "A Compisison of Alternative Estimators of a "Standard Money Demand Equation," Special Studies Paper No. 157 (Board of Governors of the Federal Reserve System, July 1981). 
mated elasticities also are similar to other estimates. For example, the estimated long-run income elasticity is 0.56 , a value that roughly coincides with the theoretical value given by a simple transactions demand framework. Finally, the summary statistics indicate that a large amount of the variation in real money balances is captured by the right-hand variables, and the error process appears well-behaved.

The regression results for the L/1960-IV/1979 period are quite unlike those of the $\mathrm{I} / 1960-1 \mathrm{~V} / 1973$ period. The estimated short-run income elasticity is halved, while the coefficient on the lagged dependent variable increases markedly. The estimated speed of adjustment ( 0.04 percent) from the $1 / 1960$ IV/ 1979 results indicates that the mean adjustment lag exceeds 26 quarters, considerably different from that for the pre-1974 period (4.5 quarters). Moreover, the estimated long-run income elasticity for the full period is now 1.50 , three times the estimate obtained from the earlier sample period.

The I/1960-IV/1979 estimates seem to support the claim that the money demand relationship has been altered. The regression evidence presented in table 1 suggests that the estimated coefficients have shifted dramatically. Moreover, a standard F-test for structural stability allows one to reject the hypothesis of stable regression coefficients across the commonly hypothesized IV/1973 break point: The calculated F-statistic of 4.51 exceeds the 5 percent critical value of $2.23 .^{8}$

Further evidence of the breakdown is demonstrated by an analysis of the equation's forecasting ability. Post-sample static forecasts for the natural $\log$ of real money balances are presented in table $2 .^{9}$ These forecasts are based on the coefficient estimates from the $\mathrm{I} / 1960-1 \mathrm{~V} / 1973$ regression. The results in table 2 indicate a continual overprediction of real money balances. The Theil bias coefficient

\footnotetext{
TSee Wiliam I. Bammol, "The Transations Demand for Cash: An Inventory Theoretic Apposch," Quarterly Jommal of Economics (November 1952), pp. 545-56: and Robert J. Baro, "Integan Constrints and Aggregation in an Enventory Model of Money Demand," Joumal of Finance (March 1976), pp. 77-78.

*his test is complicated by the presence of first-order serial correlation. In the results reported, the serial comelation coefficient $(p)$ is allowed to vary across subperiods.

Those familiar with the recent money demand litemature may find it surprising that stafic rather than dymanic forecasts are employed. The hatter technicue yields an exaggerated izicture of the shift in a relationship without proper interpretation. Consequently, the more widely understood static forecasting procedme is employed in this paner. See Scott E. Hein, "Dymamic Forecating and the Demand for Money," this Retiet Onne fuly 1980 , pp. 13-23.
}

\begin{tabular}{|c|c|}
\hline \multicolumn{2}{|c|}{$\begin{array}{l}\text { Post-Sample Static Simulation Results: } \\
\text { I/1974-1V/1979 }\end{array}$} \\
\hline \multicolumn{2}{|c|}{ Log level specification' } \\
\hline Year and Quarter & Forecast errol $\left(\times 10^{2}\right)$ \\
\hline $\begin{array}{c}1974 \\
\text { II } \\
\text { U }\end{array}$ & $\begin{array}{l}0.02 \\
1.28 \\
1.29 \\
1.60\end{array}$ \\
\hline $\begin{array}{l}19751 \\
4\end{array}$ & $\begin{array}{r}2.28 \\
0.68 \\
1.32 \\
2.51\end{array}$ \\
\hline $\begin{array}{l}1976 ! \\
\text { II } \\
\text { II } \\
\text { IV }\end{array}$ & $\begin{array}{l}1,32 \\
1,30 \\
2,2,2 \\
1.75\end{array}$ \\
\hline $\begin{array}{l}1977 \text { ! } \\
\text { II } \\
\text { IV }\end{array}$ & $\begin{array}{l}1,48 \\
2,25 \\
1,85 \\
136\end{array}$ \\
\hline $\begin{array}{l}19781 \\
9.9 \\
\text { III } \\
\text { IV }\end{array}$ & $\begin{array}{l}1.49 \\
2.41 \\
4 \\
2.26\end{array}$ \\
\hline $\begin{array}{l}19791 . \\
\text { II } \\
\text { III }\end{array}$ & $\begin{array}{l}2,66 \\
1,21 \\
1,49 \\
2,31\end{array}$ \\
\hline \multicolumn{2}{|c|}{ Sumnary statistics? } \\
\hline $\begin{array}{l}\text { RNSE } \\
\text { UM } \\
\text { US } \\
\text { UO }\end{array}$ & $\begin{array}{l}1,82(x) \\
0.682 \\
0,010 \\
0.109\end{array}$ \\
\hline
\end{tabular}

The torecast errors (actual less predicted) are logs of $\mathrm{W}$ (bllions of 1972 dollars), They are obtained from sirulating equation 1 and are based on coefficient estimates n lable 1 .

ZRMSE is the root nean squared error in lerms of red nioney balances (bilions of 1972 dollars) for the log tevel specification. 1 M is the Thel bias coeficient Us the val ance coeffucient and Ue he covariance coetticient for an expla. hatlon of these statistics, see Thel Tpphed Economil t ore. casting.

(CM) indicates that almost 90 percent of the forecast error is attributable to bias, that is, one-sided prediction errors. ${ }^{10}$ Moreover, the root-mean-squared erro: (RMSE) of 0.01782 is more than four times the insample standard error.

${ }^{10}$ For a complete description of the derivation and intenpretation of the Theil coefficients, see flenri Theil, Alphied Economic Forecrsting (Amsterdam; Notth Holland Publishing Co., 1966), pp. $27-32$. 


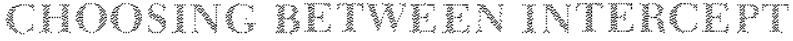 AND SIDP}

The preceding evidence suggests that the parameter estimates of equation 1 from the 1960-79 period no longer represent a viable empirical model of short-run money demand. Obviously, "some sort of shift has occurred." 11 The question is, "What tupe of shift has occurred?" If the estimated slope coefficients have changed, this implies changes in the underlying economic relationship (i.e, between real money balances and real income or interest rates). While the estimates of the slope coefficients show marked change over the two penods in table 1 , the true slope coefficients may not have actually changed. If, instead, an intercept shift occured during the mid-1970s, then empirical estimates of equation 1 for the I/1960-IV/1979 sample period may be seriously biased because of the failure to account for the level shift in the relationship, which produces a "missing variable" problem." Consequently, if the slope coefficient estimates are biased, they could lead a researcher to falsely reject the hypothesis of slope coefficient stability.

The major difficulty with an analysis of intercept shifts is in pinpointing exactly when the shift(s) ocenred. A useful procedure to determine the likely points of an intercept or slope shift is to reestimate equation 1 in first-difference form. ${ }^{13}$ Firstdifferencing equation 1 yields

$$
\text { (2) } \begin{aligned}
\Delta \ln (\mathrm{M} / \mathrm{P})_{\mathrm{t}}=\beta_{1} \Delta \ln \mathrm{y}_{\mathrm{t}}+\beta_{2} \Delta \ln \mathrm{RCP}_{\mathrm{k}} \\
+\beta_{\mathrm{s}} \Delta \mathrm{nn} \mathrm{RCB}_{\mathrm{t}}+\beta_{\mathrm{t}} \Delta \ln (\mathrm{M} / \mathrm{P})_{\mathrm{t}-\mathrm{l}}+\Delta \epsilon_{\mathrm{t}}
\end{aligned}
$$

where $\triangle$ is the first-difference operator.

Equation 2 provides useful diagnostic information in the event of an intercept shift in the level equation. For example, a once-and-for-all intercept shift in equation 1 will appear as a one-time increment in the disturbance pattern of the first-difference specification. ${ }^{14}$ Moreover, changes, if any, in the slope coefficients in equation 1 also will appear in

\footnotetext{
"Stephen M. Goldeld, "The Case of the Missing Money,"Brook inds Papers on Economic Acticitu $(3: 1976)$, p. 726 .

${ }^{2}$ Excluding a relevant variale, in this case the interept shift fem, may bias not only the coeffictent estimates, but atso the ectimate of the residnal variance. On this point see $G$. $S$ Maddala, Econometrics (MoGraw-Hill, 1977), pp. 155-57.

13 A nore complete discession of this derivation appears in $R$. W. Hafer and Scott D. Hein, "Investigating the Shift in Money Demand: An Econometrice Analysis," in Empirical Sfadies of Money Demand: Praceedings of a Conference Held at the Center for the Study of American Bustness, Working Papex No. 70 (Center for the Study of American Business, Washington University, August 1981), 1pp. 1-28.
}

equation 2. If, as many have argued, the marginal relationships embodied in equation 1 have changed, the frst-difference specification also will exhibit similar changes in the coefficient estimates. Thus, the first-difference specification serves a dual purpose: It can locate the most likely points of an intercept shift, and it provides evidence on whether the slope coefficients have changed.

To locate and test for potential intercept shifts, the following procedure was adopted: The 1/1960. IV/1979 first-difference specification (equation 2) was estimated using ordinary least squares, the residuals were plotted over time and the large residual "outliers" were selected. ${ }^{15}$ Based on this procedure, three points were identified and selected as candidates for points of intercept shift: II/1974, IV/1975 and II/1979. The first two residuals were negative, suggesting downshifts in the log-level money demand equation. The II/1979 residual was positive, suggesting an upshift. Equation 1 was estimated (again using the Hattanaka procedure) assuming onetime shits at those points using $(0,1)$ intercept dummy variables: $D I=1$ for $1 / 1960-1 / 1974,0$ otherwise; $D 2=1$ for II/I974-III/1975, 0 otherwise; and D3 =1 for IV/1975-IV/1979, 0 otherwise.

Preliminary significance tests revealed that only the II/1974 intercept shift term was statistically significant at the 5 percent level. Consequently, we report the version of equation 1 that incorporates

\footnotetext{
17his increment will be noticeable if the intercept shift is "sul ficiently large" relative to the variance of the distubances. Thus, the residuals of equation 2 are examined to determine the likely point at which "large" shifts occurred.

${ }^{15}$ The focus of this article concerns the possible intercept shift in the log-level money demand equation. Consequently, the reader s referred to Hafer and Hein, "I vestigating the Slatt in Money Demand," for a more detailed analyss of the firstdifference estimation results. To give the reader some idea of the ontcome, the OLS estimates of equation 2 for the $1 / 1960$ W/1979 period are (absolute value of t-statisties in parentheses)

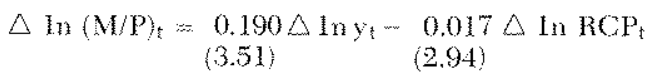$$
-0.038 \triangle \ln R C B_{t}+0.562 \triangle I_{n}(\mathrm{M} / \mathrm{P})_{t-1}
$$$$
(1,68)
$$$$
(5.79)
$$

$\overline{\mathrm{R}}^{2}=0.448$ $\mathrm{SE}=0.005$ $\mathrm{l}=0.47$
}

Not only do the coefficient estimates appear reasonably close to the pre-1974 estinates, but ex post forecasts indicate a substantial immovement in the pattern. The resultant RMSE is well within two standard error's of the equation's in sample standard eror and the Theil decomposition statistios indicate that only 7 percent of the forecast error is attributable to bias. Moreover, an $\mathrm{F}$-test for structural change at $\mathrm{W} / 1 \mathrm{gr} 3$ yields an $F$-value of 0.06 .

For a discussion of these results, see Edward K. Offenbacher, "Discussion of the Hafer and Hein, Smirlock and Webster Papers," in Empirical Studies of Money Demand, pp. 88-106. 
only the II/1974 intercept shift variable (D1). The resulting coefficient estmates are (absolute value of t-statistics in parentheses) ${ }^{\mathbf{1 6}}$

$$
\text { (3) } \begin{aligned}
& \ln (\mathrm{M} / \mathrm{P})_{\mathrm{t}}=- 0.406+0.013 \mathrm{D} 1+0.076 \ln y_{\mathrm{t}} \\
&(3.95) \quad(2.88) \quad(3.83) \\
&- 0.021 \ln \mathrm{RCP}_{\mathrm{t}}-0.020 \ln \mathrm{RCB}_{\mathrm{t}} \\
&(4.84) \quad(\mathrm{I} .28) \\
&+ 0.917 \ln (\mathrm{N} / \mathrm{P})_{\mathrm{t}-1} \\
&(16.09) \\
& \overline{\mathrm{R}} 2=0.960 \quad \mathrm{SE}=0.0048 \quad \mathrm{~h}=-0.05 \quad \rho=0.24
\end{aligned}
$$

These results support the contention that the marginal relationships in the short-run money demand equation were not altered as much as previous evidence suggests. The evidence, however, points to the existence of a significant, once-and-for-all downward level shift in the relationship in II/1974.

The regression results indicate that the constant term in the log-level specification decreased from -0.406 for the $\mathrm{I} / 1960-\mathrm{I} / 1974$ period to $-0.419 \mathrm{in}$ II/1974. This change $(0.013)$ is small relative to the standard error of the coefficient estimate. It is, however, almost three times as large as the standard error of the regression (0.0048) for the I/1960-IV/1973 period. Thus, its exclusion significantly affects the full-sample, level estimation.

A superficial comparison of the shift-adjusted, log-level estimates with those for the I/1960-IV/ 1973 sample period in table 1 suggests that the slope coefficients may have changed across the period tested. The question to be addressed now is, once the downward displacement of the constant term has been accounted for, have the slope coefficients changed statistically? To formally test this hypothesis, equation 3 was re-estimated for the full sample period with the individual slope coefficients allowed to take on different values in the two separate subperiods. Zero-one dummy variables again were used to delineate the relevant subsamples (I/1960-I/ 1974 and II/1974-IV/1979): the dummy variables are $\mathrm{DI}=1$ in $1 / 1960-1 / 19 / 4$, 0 otherwise; and D2 $=1$ in II/1974-IV/1979, 0 otherwise. The estimated equation using both the intercept and slope

\footnotetext{
16 The use of the dimmy variable for the $\mathrm{H} / 1960-\mathrm{l} / 1974$ period and the constant term is interpreted in the following manner: The true constant term for the $\mathrm{I} / 1960-\mathrm{I} / 1974$ period is obtained by adding the estimated constant and the estimate on the dummy variable. The constant for the II/1974-IV/1979 period is represented by the estimate of the constint term reported in the text.
}

dummy variables is (absolute value of t-statistics in parentheses) ${ }^{17}$

$$
\begin{aligned}
& \ln (\mathrm{N} / \mathrm{P})_{\mathrm{t}}=-0.482-0.008 \mathrm{D} 1+0.099 \mathrm{D} 1 \ln \mathrm{y}_{\mathrm{t}} \\
& \begin{array}{lll}
(2.76) \quad(0.53) \quad(2.61)
\end{array} \\
& +0.124 \mathrm{D} 2 \ln \mathrm{y}_{\mathrm{t}}-0.018 \mathrm{DI} \mathrm{In} \mathrm{RCP}_{\mathrm{t}} \\
& \text { (3.69) (3.41) } \\
& \text { - 0.013 D2 } 1 n \mathrm{RCP}_{\mathrm{t}} \\
& \text { (1.76) } \\
& \text { - } 0.019 \mathrm{DI} \ln \mathrm{RCB}_{\mathrm{t}} \\
& \text { (1.39) } \\
& -0.015 \mathrm{D} 2 \text { In } \mathrm{RCB}_{\mathrm{t}} \\
& \text { (0.15) } \\
& +0.832 \mathrm{D}) 1 \ln (\mathrm{M} / \mathrm{P})_{t-\mathrm{I}} \\
& \text { (7.45) } \\
& +0.560 \mathrm{D} 2 \ln (\mathrm{M} / \mathrm{P})_{t-1} \\
& \text { (2.77) } \\
& \overline{\mathrm{R}}^{2}=0.969 \quad \mathrm{SE}=0.0044 \quad \mathrm{DW}=1.90
\end{aligned}
$$

Standard t-tests were used to test the hypothesis that each slope coefficient had remained stable once the downward level shift in I/1974 had been taken into account. The resulting t-statistics indicate that each coefficient had not changed statistically over the full-sample period. The variables and the t-statistics for their coefficients are In y (0.43), ln RCP (0.19), $\ln \operatorname{RCB}(0.03)$ and $\ln (\mathrm{M} / \mathrm{P})_{\mathrm{t}-1}$ (1.35). This evidence supports the view that money demand was subject to a level not a slope shift during the mid-1970s. ${ }^{18}$

The purpose of this article has been to investigate the nature of the shift in the conventional money demand specification that occurred cluring the mid1970s by determining whether it was an intercept or slope shift. The empirical results presented in this article indicate that the conventional equation was subject to a level, and not a slope, shift in early 1974. Our analysis of the first-difference results and the

\footnotetext{
${ }^{17}$ Sunce the Hatamaka procedure requires estimation of the residwal error in the last-stage equation, it, too, was constrained in the above manner. A test revealed that neither the error process nor $p$ had changed. This procedure, in conjunction with the dummy variable teat, produdes olstaining a dircct costinate of $p$.

${ }^{18}$ If the preceding evidence were not sufficient to sway the skeptical reader, more support comes from the shift-adjusted, log-level equation's ex post forecasting record: The RMSE for the shift-adjusted equation for the period II/1974-IV/1979 is $0.67\left(\times 10^{-2}\right)$. This value is well within two standard errors of the estimating equation's in-sample standard error, and is less than half the RMSE reported in table $2\left(1.782 \times 10^{-2}\right)$.
} 
W

properly specified log-level equation suggests that II/1974 is the most likely point of the significant downward shift in the money demand function.

An important implication of this study is that the economic relationships inherent in the conventional money demand function are more stable than previous investigations have suggested. Changes in money demand since II/1974 can be explained by changes in the exogenous variables without relying on tenuous assertions that the underlying economic relationships have degenerated. Although previons analyses have suggested that there has been a con- tinuous, mexplained deterionation of the money demand function after 1973, our andysis suggests that the marginal relationships have remained stable over the $\mathrm{U} / 1960-\mathrm{IV} / 1979$ period, providing useful information in estimating the level of money demand. ${ }^{19}$ Thus, clams that the shortmm money demand finction is highly unstable and is responsible for the entatic behavior of money growth during this period must be reconsidered.

${ }^{19} \mathrm{Fon}$ example, see Stephen H. Axjlrod azod David E. Lindsey, "Federal Resene System Implementation of Monetary Policy: Andytical loundations of the New Approuds," Anerican Economie Retion (Nay 1981 ) pr. 246,52 . 